\title{
CCNA1 wt Allele
}

National Cancer Institute

\section{Source}

National Cancer Institute. CCNA1 wt Allele. NCI Thesaurus. Code C104228.

Human CCNA1 wild-type allele is located within 13q12.3-q13 and is approximately $11 \mathrm{~kb}$ in length. This allele, which encodes cyclin-A1 protein, plays a role in the control of the cell cycle at the G1/S and G2/M transitions. 